\title{
The mineralogical composition of calcium and calcium-magnesium carbonate pedofeatures of calcareous soils in the European prairie ecodivision in Hungary
}

\author{
Géza Szendrei \\ Hungarian Natural History Museum, Budapest
}

\author{
Péter Kovács-Pálffy, Mária Földvári \\ Geological and Geophysical Institute of Hungary, \\ Budapest
}

\author{
Kamilla Gál-Sólymos \\ Eötvös Loránd University, Budapest
}

\begin{abstract}
There is little data on the mineralogy of carbonate pedofeatures in the calcareous soils in Hungary which belong to the European prairie ecodivision. The aim of the present study is to enrich these data

The mineralogical composition of the carbonate pedofeatures from characteristic profiles of the calcareous soils in Hungary was studied by X-ray diffractometry, thermal analysis, SEM combined with microanalysis, and stable isotope determination.

Regarding carbonate minerals only aragonite, calcite (+magnesian calcite) and dolomite (+ protodolomite) were identified in carbonate grains, skeletons and pedofeatures.

The values relating, respectively, to stable isotope compositions $\left(\mathrm{C}^{13}, \mathrm{O}^{18}\right)$ of carbonates in chernozems and in salt-affected soils were in the same range as those for recent soils (latter data reported earlier). There were no considerable differences between the values for the carbonate nodules and tubules from the same horizons, nor were there significant variations between the values of the same pedofeatures from different horizons $(\mathrm{BC}-\mathrm{C})$ of the same profile. Thus it can be assumed that there were no considerable changes in conditions of formation.

Tendencies were recognized in the changes of (i) carbonate mineral associations, (ii) the $\mathrm{MgCO}_{3}$ content of calcites, (iii) the corrected decomposition temperatures, and (iv) the activation energies of carbonate thermal decompositions among the various substance-regimes of soils.

Differences were found in substance-regimes types of soils rather than in soil types.
\end{abstract}

Key words: carbonate nodules, tubules, needle-fiber calcite, earthworm biospheroids, calcite, magnesian calcite, dolomite, protodolomite

\footnotetext{
Addresses: G. Szendrei: H-1088 Budapest, Baross u. 13, Hungary, e-mail: szendrei@miner.nhmus.hu P. Kovács-Pálffy, M. Földvári: H-1143 Budapest, Stefánia u. 14, Hungary

K. Gál-Sólymos: H-1117 Budapest, Pázmány P. sétány 1/C, Hungary

Received March 30, 2012; accepted: January 25, 2013
} 


\section{Introduction}

Calcium and calcium-magnesium carbonates show very interesting distinctions with respect to composition, solubility, etc. They exert important impacts on soil properties like $\mathrm{pH}$, puffer capacity, calcium and magnesium supply, cation and anion adsorption, and the soil structure. The mentioned properties play a decisive role in soil-forming processes and soil use.

The study of the pedofeatures (formed by concentration or separation of some kinds of components) is of significant importance because pedofeatures are considered to be carriers of valuable information related to the formation processes of soils.

The relevant relationships were based mostly on the morphology, inner structure, size, and distribution of calcareous pedofeatures. Scant attention was paid to the relationships with carbonate minerals of the pedofeatures (Gerasimova et al. 1996; Doner and Lynn 1989; Lal et al. 2000; Szendrei 2000, 2001; Doner and Grossl 2002; Durand et al. 2010).

Although a considerable part of the calcareous soil types in the soil cover of Hungary has been characterized micromorphologically (Szendrei 2001), data on the mineralogical composition of the calcareous pedofeatures have not yet been published.

In order to study the carbonate pedofeatures of calcareous soils in the European prairie ecodivision (according to Bailey 1995), it is obviously necessary to select Hungary where a series of calcareous soils with various formation processes occurs.

The aims of this investigation are to characterize the carbonate minerals of calcareous pedofeatures in the calcareous soil types and to contribute to the knowledge about their formation.

\section{Materials}

In accordance with the above-mentioned aims, calcareous soil types of the different main types were selected for sampling.

Samples of the typical profiles of various soil types collected between 1985 and 2000 to characterize the micromorphology of the Hungarian soils were available and were used in this investigation. The micromorphological descriptions (Szendrei 2001) connected to these samples were very useful as a background.

For this study 21 characteristic profiles of calcareous soil types were selected.

The soil types - according to the Hungarian soil classification system, their code numbers, sites, and their correlation (Micheli et al. 2006; Sisák and Máté 2008) with the World Reference Base for Soil Resources Systems (FAO/ISRIC/ISSS 1998) - are shown in Table 1. The location of the sites can be seen in Fig. 1.

The description of the profiles was performed using standard methods. Sampling of genetic horizons was performed in the usual way for soil investigations, focusing on various aspects of soil genetics (Szabolcs 1966). 
Table 1

Codes of soil types; soil types according to the Hungarian soil classification and correlations with World Reference Base for Soil Resources (WRB) System (1998), locations of sites

\begin{tabular}{|c|c|c|c|}
\hline Codes & $\begin{array}{l}\text { Soil types according to the } \\
\text { Hungarian soil classification }\end{array}$ & Correlations with the WRB & Location of sites \\
\hline 6 & Humus carbonate soil & Calcisol & Budapest \\
\hline 7 & Rendzina & Rendzic Leptosol & Budapest \\
\hline 11 & Brown forest soil with clay illuviation & Luvisol & Kisgörbő \\
\hline 15 & $\begin{array}{l}\text { Brown forest soil with carbonate } \\
\text { residue }\end{array}$ & Calcaric Cambisol & Nemti \\
\hline 16 & Chernozem brown forest soil & Luvic Chernozem & $\begin{array}{l}\text { Bonyhád, } \\
\text { Szekszárd }\end{array}$ \\
\hline 18 & Leached chernozem & Phaeozem & Tiszalúc \\
\hline 19 & Pseudomyceliar chernozem & Calcaric Chernozem & Baracska, Látókép \\
\hline 20 & Meadow chernozem & Gleyic Chernozem & $\begin{array}{l}\text { Sárszentlörinc, } \\
\text { Törökszentmiklós }\end{array}$ \\
\hline 24 & Meadow solonetz soil & Solonetz & $\begin{array}{l}\text { Hortobágy, } \\
\text { Szarvas }\end{array}$ \\
\hline 25 & Steppe meadow solonetz & Sodic Vertisol & Püspökladány \\
\hline 28 & Solonchak meadow solonetz & Mollic Solonchak & Sarkad \\
\hline 29 & Solonetzic meadow soils & Sodic Vertisol & Szarvas \\
\hline 30 & Meadow soil & Haplic Vertisol & $\begin{array}{l}\text { Besenyszög, } \\
\text { Szarvas }\end{array}$ \\
\hline 31 & Alluvial meadow soils & Humic Gleysol & Szarvas \\
\hline 32 & Peaty meadow soil & Mollic Gleysol & Szeghalom \\
\hline 40 & Soil of slope deposits & Regosol & Sárszentlörinc \\
\hline
\end{tabular}

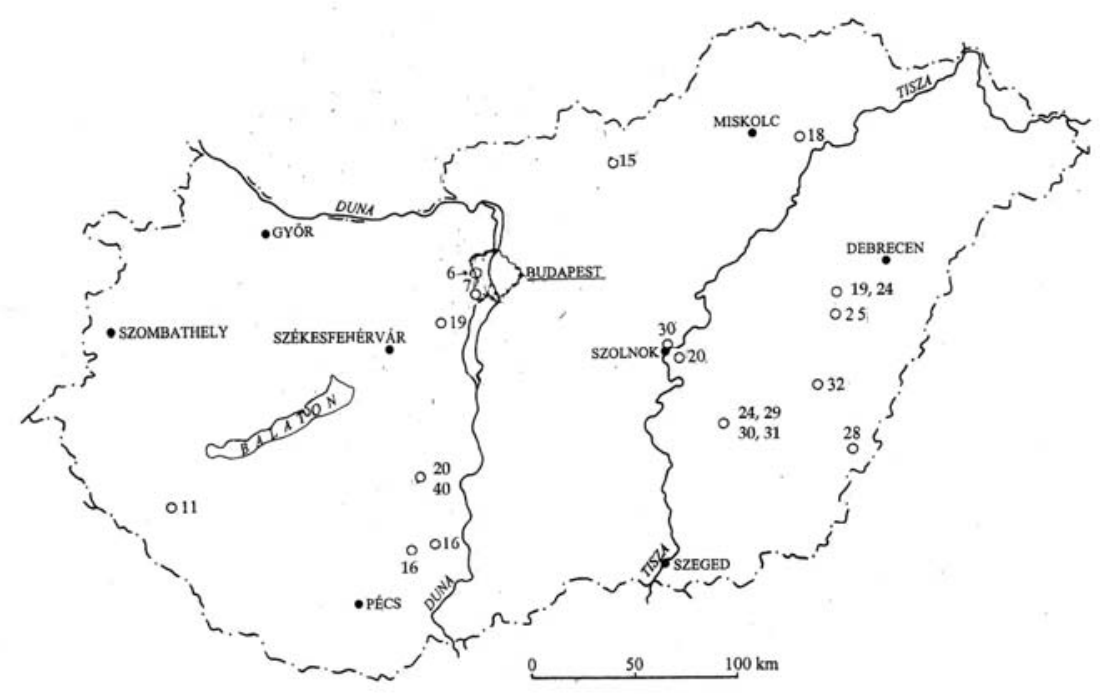

Fig. 1

The location of sample sites. See numbers in Table 1 
From the samples, the following various calcareous features were investigated: nodules, tubules, earthworm biospheroids and needle fiber crystals.

The definitions of these features were given as follows:

- "nodules are more or less equidimensional pedofeatures that are not related to natural surfaces and voids and that do not consist of single crystals or crystal intergrowths" (Bullock et al. 1985, modified cit. Stoops 2003).

- tubules are composite pedofeatures consisting of hypocoatings and coatingsinfillings. Coatings: "These are pedofeatures that coat the surfaces of voids, grains and aggregates." Hypocoatings: "These occur immediately adjoining rather than on the surface with which they are associated." Infillings: "These are formed of soil material, or some fraction of it, infilling or partly infilling voids" (after Bullock et al. 1985).

- needle-fiber calcites are generally coatings or infillings,

- "biospheroids of calcite, 0.4-2 mm in diameter, composed of an outer layer of pure coarse calcite with an incomplete radial fabric and finer crystals in the center, are secreted by earthworms" (after Bal 1977; Becze-Deák et al. 1997; Canti 1998 cit. Stoops 2003).

For comparison, carbonate grains and skeletons were selected from some soils.

\section{Methodology}

Size fractions above $1 \mathrm{~mm}$ were separated by sieving; the grains, skeletons and calcitic pedofeatures were separated by hand-picking under a Nikon SMZ-U-type microscope. This work was carried out in the former Geological Institute of Hungary and the Department of Mineralogy and Petrology of the Hungarian Natural History Museum.

Carbonate minerals cannot be separated from calcareous nodules and tubules without destruction. This is mainly due to the cementing material consisting of calcium-magnesium carbonates. Therefore only XRD and SEM-EDX can be used, rather than chemical analysis (e.g. determination of $\mathrm{MgCO}_{3}$ in calcite and protodolomite).

Thermal analysis was carried out in a PC-controlled Derivatograph and evaluated by computer, with simultaneous TG, DTG and DTA recordings. Corundum crucibles, $\mathrm{Al}_{2} \mathrm{O}_{3}$ inert material, and $10{ }^{\circ} \mathrm{C} / \mathrm{min}$ heating velocity (up to $1000{ }^{\circ} \mathrm{C}$ ) were used.

The corrected thermal decomposition temperature and the activation energy of the carbonates were determined. The software of the computerized Derivatograph contains a simple method for estimating the formal-kinetic parameters (Arnold et al. 1987).

For the characterization of the calcite mineral, the corrected (or interpolated) decomposition temperature was also used (instead of the measured peak temperature). The use of this parameter allows eliminating the temperature differences of a given reaction caused by the different quantity of the phases 
involved in the reaction (Földvári 1999). From the differences between the measured and the comparative standard decomposition temperatures, conclusions on other factors which influence the decomposition temperature (e.g. crystallinity, substitution, different geologic processes such as weathering, diagenesis etc.) may be drawn. This study was performed by the Thermal Laboratory of the former Geological Institute of Hungary.

X-ray diffractograms were prepared with a Phillips PW 1730 diffractometer (controlled and evaluated by computer). The parameters of the investigations were: $\mathrm{Cu}$-anticathode, $40 \mathrm{kV}$ and $30 \mathrm{~mA}$ tube current, graphite monocromator, and 2 theta $\%$ min goniometer speed. The mineralogical composition was calculated by taking into account the relative intensity ratios of the characteristic reflexions of minerals and the corundum factors.

In the case of parallel data of semi-quantitative XRD and thermal analysis the accuracy is generally $\pm 5 \%$. When only semi-quantitative XRD is available, the accuracy is up to $10 \%$.

XRD can be used to calculate the amount of $\mathrm{Mg}$ entering the calcite lattice. The scale of isomorphic replacement was calculated from the highest (104) reflection $=2944^{\circ}$ 2theta) with the help of determination curves (Szemethy 1975; KovácsPálffy et al. 2000). This study was performed by the X-ray Laboratory of the former Geological Institute of Hungary.

The samples were investigated using an AMRAY 1830 I/T6 SEM, equipped with an EDAX PV9800 energy dispersive spectrometer, using $20 \mathrm{KeV}$ accelerating potential and 1-2 nA beam current. The evaluations of ED spectra were made by ZAF-correction using the standardless program of instruments. The measurements were carried out at the Eötvös Loránd University, Department of Petrology and Geochemistry.

Carbon and oxygen isotope compositions of bulk soil samples were determined using the conventional $\mathrm{H}_{3} \mathrm{PO}_{4}$ digestion method at $25{ }^{\circ} \mathrm{C}$ (McCrea 1950). The ${ }^{13} \mathrm{C} /{ }^{12} \mathrm{C}$ and ${ }^{18} \mathrm{O} /{ }^{16} \mathrm{O}$ ratios of the $\mathrm{CO}_{2}$ generated were measured using a Finningan MAT delta S mass spectrometer; this was carried out at the Institute for Geochemical Research in Budapest. Standardization was conducted using laboratory calcite standards calibrated against the NBS-19 standard. The results are expressed in the $\delta$-notation $\left.\left[\delta=R_{1} / R_{2}-1\right) \times 1000\right]$ where $R_{1}$ is the ${ }^{13} C /{ }^{12} C$ or ${ }^{18} \mathrm{O} /{ }^{16} \mathrm{O}$ ratio in the sample, and $\mathrm{R}_{2}$ is the corresponding ratio of the standard ( $\mathrm{V}$ PDB for C and V-SMOW for O), in \%o]. Reproducibilities are better than $\pm 0.2 \%$ (Demény and Fórizs 1991).

\section{Results and discussion}

The results of the investigations are discussed in the following sequence: (a) grains and skeletons, (b) nodules and tubules, (c) biospheroids (d) needle-fiber calcites. 
The respective interpretations of the data are usually based on a comparison of data among various calcareous pedofeatures or of one kind of pedofeature among different soil types, or substance-regimes of soil types.

The amounts of the different carbonate minerals determined by X-ray diffractometry and thermal analysis are given in Table 2 . The differences in the quantities of calcium carbonate minerals determined by XRD and thermal analysis were within or equal to $5 \%$ in $90 \%$ of samples. The differences that were higher than $5 \%$ were due to the variations of calcite/dolomite ratios or to the slight underestimation of aragonite contents.

\section{Grains and skeletons}

Grains were separated from the A, B, BC and C horizons of humus carbonate, from the $A$ and $B$ horizons of rendzina, and from the $B$ and $B C$ horizons of brown forest soil with carbonate residues. The respective average calcite contents were $85 \%$ and $84 \%$ (with extremes of $47-100 \%$ and $43-96 \%$ ). The first set of values was calculated using the data of X-ray diffractometry, while the second set used the data of thermal analysis.

Aragonite was found in six samples as skeleton fragments $(39 \%, 8-86 \%)$.

$\mathrm{MgCO}_{3}$ content in calcite samples was below the detection limit of X-ray diffractometry.

\section{Nodules and tubules}

X-ray diffractometry and thermal analysis

The nodules, and in part the tubules (Plate I. Figs 1 and 2), were mainly formed by cementation from calcareous soil solutions impregnating the groundmass (i.e. grains, skeletons, fine material and micropores), or by precipitation along the pore walls. This observation was supported by data on the mineralogical composition of the nodules and tubules (Tables 2 and 3 ) because the calcite content was large and the proportion of non-carbonate minerals was considerable.

There was good conformity between the average and extreme values of the calcite content, and the average of the dolomite content determined by X-ray diffractometry and thermal analysis (Table 2).

The respective averages of the calcite content and the extreme quantities in the nodules and tubules were nearly the same.

A distinction can be made on the basis of the presence or absence of euhedral sparitic calcite crystals: these were represented by rhombohedra, elongated pyramids, tables and lamellae, etc. Such euhedral sparitic calcite crystals can be found in, or on, tubules separated from solonetzic meadow (BC and $C$ horizons) and meadow soil (BC horizon). 
Plate I

1. Nodules from meadow solonetz soil, C horizon. Width of picture $20 \mathrm{~mm}$

2. Tubules from meadow solonetz soils, $\mathrm{C}$ horizon. Width of picture $12 \mathrm{~mm}$

3. BEI of calcium carbonate groundmass (light grey) with protodolomite pore infillings (dark grey: 1 ) in a nodule from meadow solonetz, $\mathrm{C}$ horizon

4. BEI of calcium carbonate groundmass (light grey: 2) with protodolomite pore infillings (dark grey: 1) in a nodule from meadow solonetz, $\mathrm{C}$ horizon

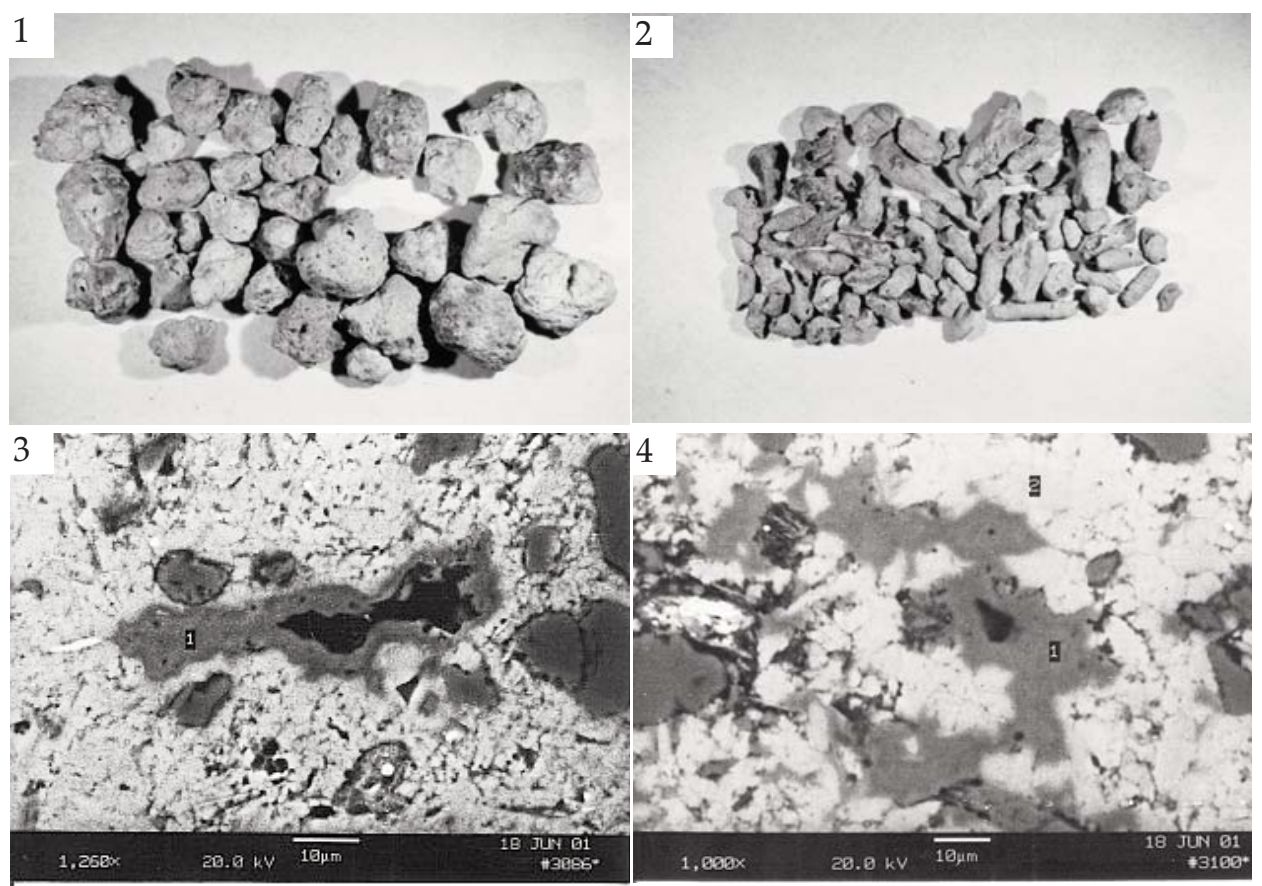

The respective average of the dolomite content in the nodules and tubules produced a reasonable fit, although there were certain differences in these extremes (Table 2).

The frequency of occurrences of low-magnesian calcite was almost $60 \%$ in nodules and tubules, the average amount of $\mathrm{MgCO}_{3}$ was $1.6 \%$, and the maximum values were generally below $4 \%$. There was no difference between the averages and extremes of nodules and tubules $-1.6 \%(0-4 \%)$ - with respect to $\mathrm{MgCO}_{3}$. A distinction can be made between the $\mathrm{MgCO}_{3}$ content of calcite in nodules, and also in tubules, with respect to salt-affected and non salt-affected soils. In the calcitic pedofeatures of salt-affected soils the frequency of occurrences was two times larger than in non-salt-affected soils; the average of $\mathrm{MgCO}_{3}$ content was almost three times larger ( $2.3 \%$ vs. $0.8 \% \mathrm{MgCO}_{3}$ content in calcite) than in nonsalt-affected soils. 
404 G. Szendrei et al.

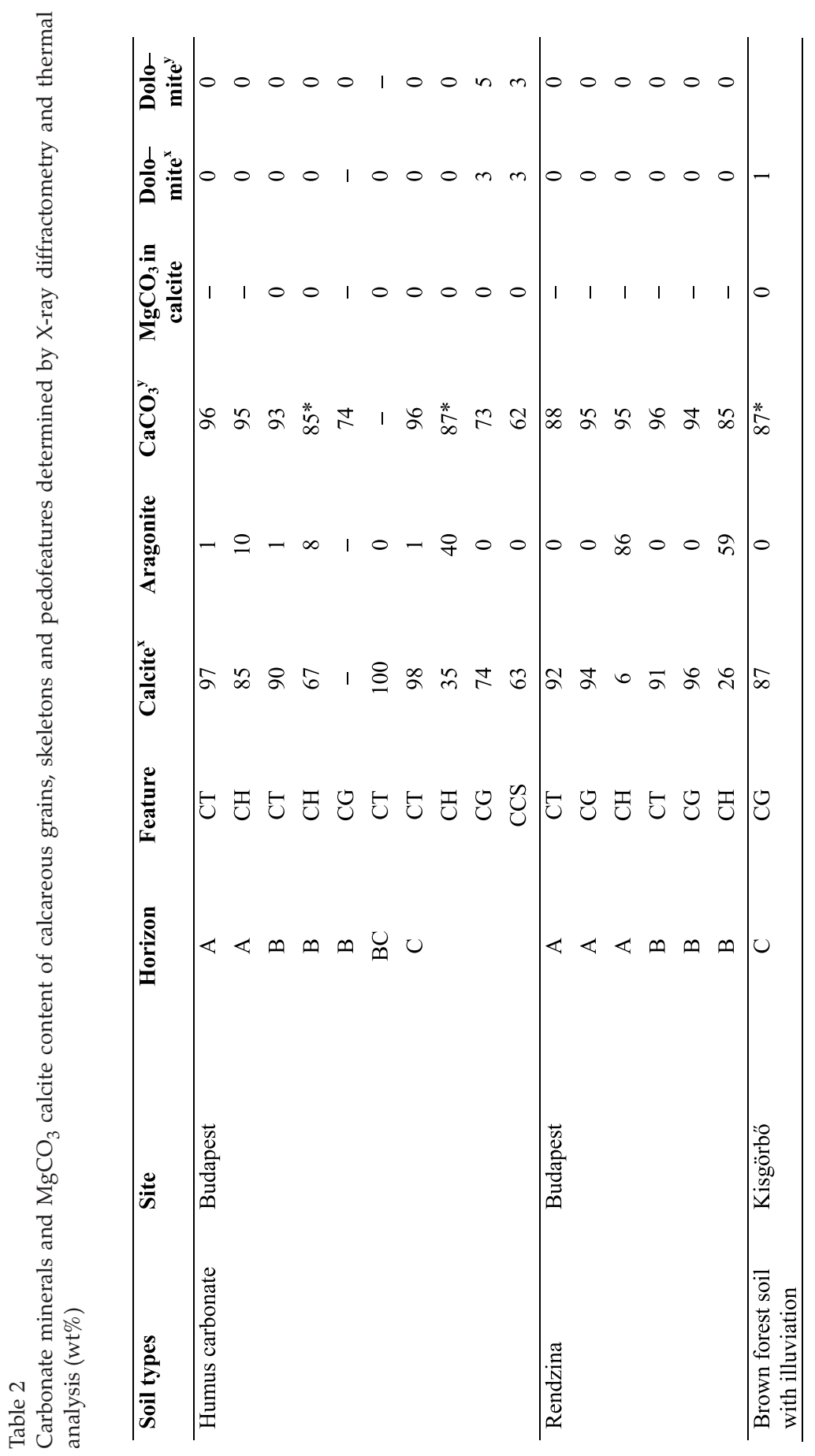

Central European Geology 55, 2012 
The mineralogical composition of calcareous soils in the European prairie ecodivision in Hungary 405

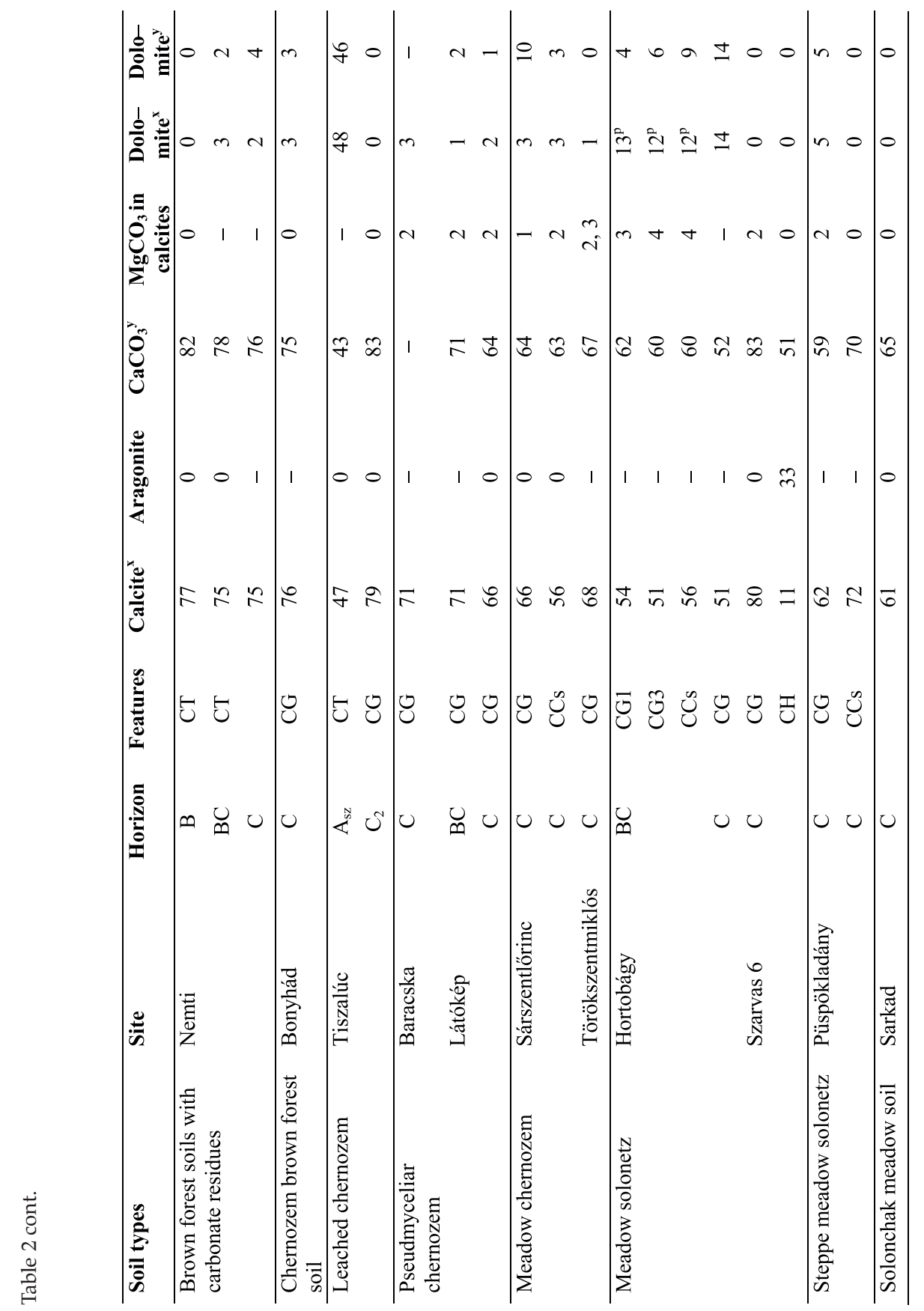


406 G. Szendrei et al.

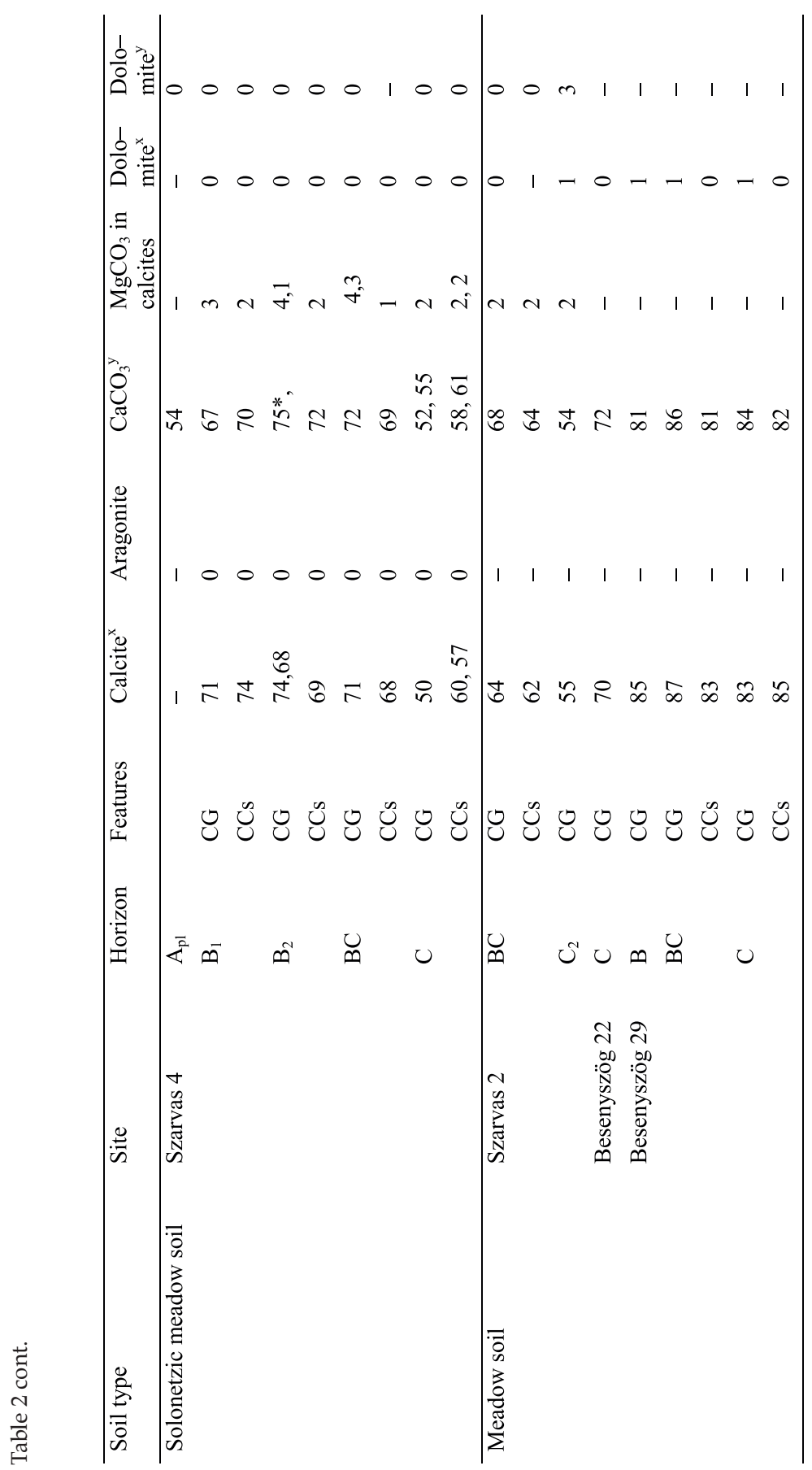

Central European Geology 55, 2012 
The mineralogical composition of calcareous soils in the European prairie ecodivision in Hungary 407

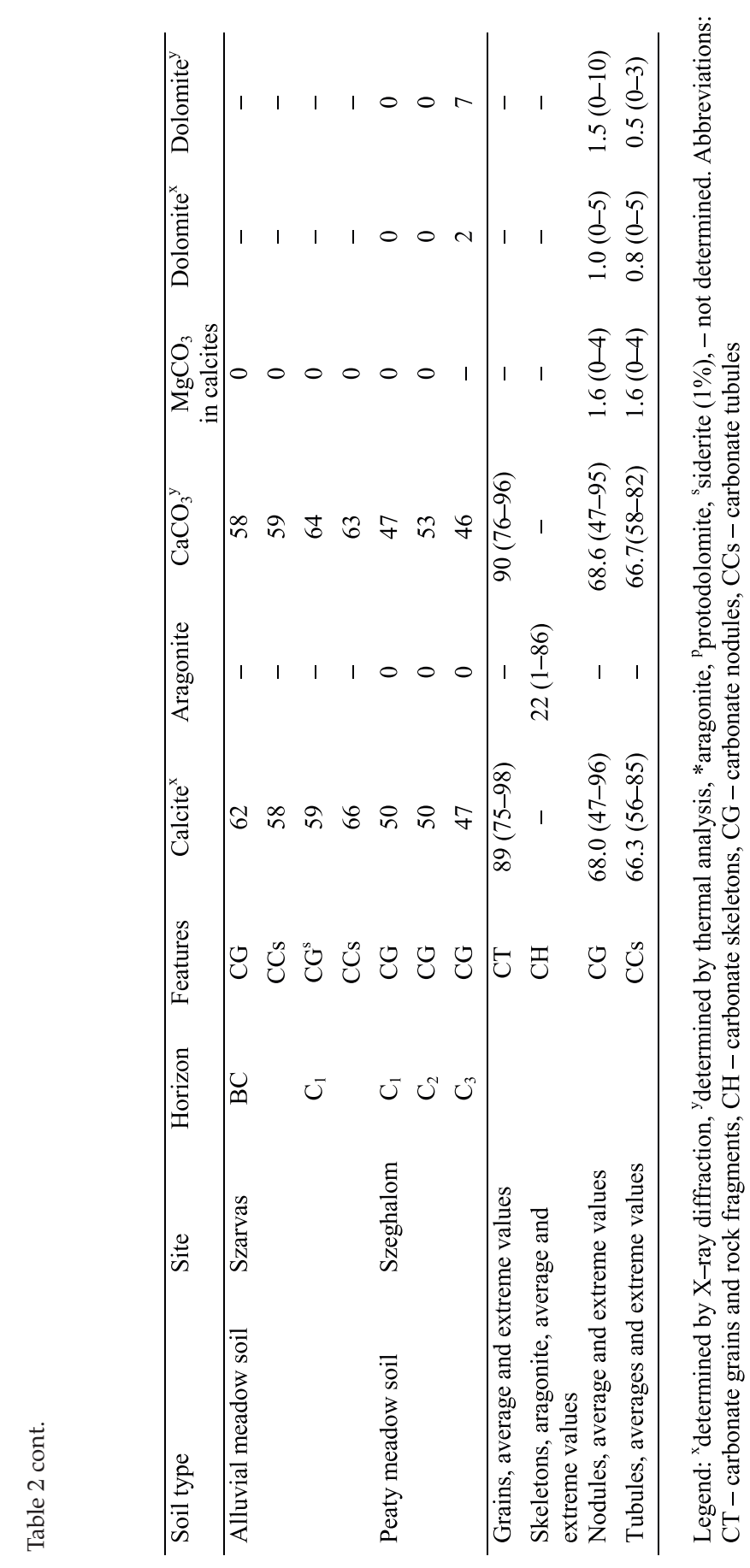

Central European Geology 55, 2012 
Table 3

Non-carbonate minerals $(\mathrm{wt} \%)$ in calcareous pedofeatures determined by X-ray diffractometry

\begin{tabular}{|c|c|c|c|c|c|c|c|c|}
\hline & Quartz & Plagioclase & Muscovite & Chlorite & Goethite & Illite & $\begin{array}{c}\text { Montmo- } \\
\text { rillonite }\end{array}$ & Amphibole \\
\hline $\begin{array}{l}\text { Nodules } \\
\text { average } \\
\text { extremes }\end{array}$ & $\begin{array}{l}13.5 \\
1-27\end{array}$ & $\begin{array}{c}4.5 \\
0-12\end{array}$ & $\begin{array}{l}1.5 \\
0-7\end{array}$ & $\begin{array}{l}2.5 \\
0-6\end{array}$ & $\begin{array}{c}1.4 \\
0-25\end{array}$ & $\begin{array}{l}3.5 \\
0-7\end{array}$ & $\begin{array}{l}2.5 \\
0-8\end{array}$ & $<1$ \\
\hline $\begin{array}{l}\text { Tubules } \\
\text { average } \\
\text { extremes }\end{array}$ & $\begin{array}{l}15.7 \\
7-26\end{array}$ & $\begin{array}{l}4.2 \\
2-6\end{array}$ & $\begin{array}{l}2.7 \\
0-8\end{array}$ & $\begin{array}{l}3.5 \\
2-6\end{array}$ & $<1$ & $\begin{array}{l}3.5 \\
0-8\end{array}$ & $\begin{array}{l}2.8 \\
0-6\end{array}$ & $<1$ \\
\hline & Biotite & Hematite & $\mathrm{K}$-feldspar & Kaolinite & $\begin{array}{l}\text { Illite- } \\
\text { montmo- } \\
\text { rillonite }\end{array}$ & Talc & Zeolites & \\
\hline $\begin{array}{l}\text { Nodules } \\
\text { average } \\
\text { Tubules } \\
\text { average }\end{array}$ & $\begin{array}{l}<1 \\
<1\end{array}$ & $<1$ & $<1$ & $<1$ & $\begin{array}{l}<1 \\
<1\end{array}$ & $\begin{array}{l}<1 \\
<1\end{array}$ & $<1$ & \\
\hline
\end{tabular}

These findings are in accordance with earlier studies regarding the $\mathrm{MgCO}_{3}$ content of calcites in chernozem and salt-affected soils, e.g. in Saskatchewan (Canada) and in Argentina. St. Arnaud and Herbillon (1973) found lowmagnesian calcite in upland chernozems and high-magnesian calcite in chernozems in depressions and in the subsoils of solonetz soils. St. Arnaud (1979) did not mention the presence of magnesian calcite in non-salt-affected horizons, but it can be found in salt-affected horizons of chernozem soils. Very lowmagnesian calcite is present in dark brown chernozem, and in salt-affected soils calcite containing 3\% $\mathrm{MgCO}_{3}$ was noted by Ghebre-Egziabhier and St. Arnaud (1983). Lavado (1983) found low-magnesian calcite in Mollisoils and highmagnesian calcite in natric and salic horizons (in Argentina).

The partitioning coefficient of $\mathrm{Mg}$ in calcites (at ambient temperature) is $0.015-0.027$ [ $<8 \mathrm{~mol} \% \mathrm{MgCO}_{3}$ ] (Mucci and Morse 1983). Consequently, a high ratio of $\mathrm{Mg} / \mathrm{Ca}$ in solution is necessary for the formation of magnesian calcite.

In some salt-affected soils in Hungary the magnesium content decreases from the groundwater to the soil solution of top soils. Earlier it was published that magnesium can be incorporated into clay minerals in salt-affected soils (Darab and Reményi 1978). The investigations discussed here prove that formation of carbonate minerals is also involved in the process, which causes a decrease in magnesium ion concentration in soil solutions.

In the investigated salt-affected soil, a carbonate mineral with a higher magnesium carbonate content was also detected. In the nodules and tubules from the BC horizon of meadow solonetz soil, $12-13 \%$ protodolomite was determined by $\mathrm{X}$-ray diffraction. The BEI study also showed the presence of pore infillings (Plate I, Figs 3, 4). 
The Mg and Ca quantities detected by microanalysis (Table 4) were close to the value of protodolomite: $\mathrm{Ca}_{60} \mathrm{Mg}_{40}$ (Graf and Goldschmidt 1955). The embedding groundmass consisted of calcite with low amounts of magnesium.

In Hungary protodolomite was found in the lacustrine deposits of lakes Balaton and Fertő (Müller and Wagner 1980; Molnár and Dinka 1997); it was also found in the fluviatile, alluvial clay-siltstone sequence cut by boreholes in the Bodrogköz, and in the Szatmári lowlands (Szöör et al. 1992).

Dolomite has also been found in the lacustrine sediments of the saline lakes in the Danube-Tisza interfluve, but protodolomite was not present (Molnár and Botz 1996).

Suarez (2005) mentioned the occurrence of protodolomite in salt-affected soils.

Some laboratory experiments have been carried out - under a variety of conditions - in order to synthesize protodolomite (Graf and Goldschmidt 1955; Ohde and Kitano 1978; Oomori et al. 1983; Fujimori et al. 2006); in these experiments the optimal $\mathrm{Mg} / \mathrm{Ca}$ ratios were very different.

Numerous models have been worked out to explain the results (Warren 2000); of these, the formation of dolomite in hypersaline water, and the mixing of fresh and brackish water models can be taken into consideration with respect to the soil conditions.

A relationship was revealed between the calcium-magnesium carbonate mineral associations and substance-regime types in soils (substance-regime types of soils were given by Várallyay 1985):

- a calcite and dolomite association is present in the nodules and tubules of the C-horizons in soils with leached and equilibrium substance-regimes (humus carbonate, brown forest soils with clay illuviation, chernozem brown forest soil, and brown forest soil with carbonate residues);

- a calcite, magnesian calcite, dolomite association can be found in calcareous pedofeatures of subsoils with equilibrium- and accumulation-types of substanceregimes (pseudomyceliar chernozem, meadow chernozem and meadow soils, alluvial meadow soil and peaty meadow soil);

Table 4

Microanalysis of protodolomites and surrounding materials. Meadow solonetz soil

\begin{tabular}{lllcc}
\hline Carbonatic components & Horizon & Pedofeatures & $\begin{array}{c}\mathbf{M g C O}_{3} \\
\text { mole\% }\end{array}$ & $\begin{array}{c}\mathbf{C a C O}_{3} \\
\text { mole\% }\end{array}$ \\
\hline Protodolomite infilling & $\mathrm{BC}$ & 'G3' nodule & 39.5 & 60.5 \\
groundmass & $\mathrm{BC}$ & groundmass & 2.2 & 97.8 \\
Protodolomite infilling & $\mathrm{BC}$ & 'G3'nodule & 37.5 & 62.5 \\
Protodolomite infilling & $\mathrm{C}$ & nodule & 40.0 & 60.0 \\
Protodolomite infilling & $\mathrm{C}$ & nodule & 34.5 & 65.5 \\
Protodolomite infilling & $\mathrm{C}$ & nodule & 43.1 & 56.9 \\
groundmass & $\mathrm{C}$ & groundmass & 4.4 & 95.6 \\
Protodolomite infilling & $\mathrm{C}$ & nodule & 40.5 & 59.5 \\
\hline
\end{tabular}


- a calcite, magnesian calcite, dolomite, protodolomite association is present in the nodules and tubules of soils with substance-regimes of medium sodium accumulations (meadow solonetz).

\section{Determination of thermal parameters}

In order to give a detailed characterization of the mineralogical nature of calcium carbonate pedofeatures, the corrected thermal decomposition temperature and the activation energy of the carbonates were determined.

The corrected thermal decomposition and activation energy of carbonates in the nodules and tubules were somewhat lower (with considerable standard deviations) than the equivalent figures for the grains (Table 5).

Table 5

Corrected decomposition temperature and activation energy of the thermal decomposition of calcite in calcareous grains, skeletons and pedofeatures

\begin{tabular}{lccc}
\hline Features & Samples & $\begin{array}{c}\text { Corrected } \\
\text { decomposition } \\
\text { temperature* }\end{array}$ & $\begin{array}{c}\text { Activation } \\
\text { energy* }\end{array}$ \\
\hline & number & ${ }^{\circ} \mathrm{C}$ & kjoule/mole \\
\hline Grains & 8 & $911(4)$ & $369(21)$ \\
Skeletons & 7 & $907(7)$ & $351(19)$ \\
(aragonite) & 32 & $904(10)$ & $329(36)$ \\
Nodules & 32 & $901(6)$ & $313(46)$ \\
Tubules & 15 & & \\
\hline
\end{tabular}

*average (standard deviations)

The datasets were divided into groups according to the types of substanceregimes of the soils (Table 6). The groups were as follows:

a) substance-regime with slight leaching (brown forest soils with clay illuviation, chernozem brown forest soil, and leached chernozem),

b) substance-regime with equilibrium (pseudomyceliar and meadow chernozem),

c) substance-regime under the impact of groundwater - with carbonate accumulations (meadow, alluvial meadow and peaty meadow soils),

d) substance-regime with moderate sodium accumulation (e.g. solonetzic meadow and meadow solonetz soils).

The data for lithogenic soils (e) were given for comparison.

According to the list above, a slight tendency was observed in the sequence ea-b-c-d (Table 6).

The values were the highest for the grains from lithogenic soils, and the values were still high for soil with slight leaching; this is due to the fact that they were from the parent rocks. In the soil with substance-regimes with accumulation, the formations of carbonate minerals have to be taken into account. The values showed a tendency to decrease and this can be interpreted alongside the diminishing crystallinity of the at least partly secondary carbonate minerals. Distinct differences were noticeable between the values of lithomorphic and saltaffected soils. 
Table 6

Corrected decomposition temperature and activation energy of the calcite grouped according to the types of substance regimes of soils

\begin{tabular}{|c|c|c|c|}
\hline Type of substance regime & Samples & $\begin{array}{c}\text { Corrected } \\
\text { decomposition } \\
\text { temperature* }\end{array}$ & $\begin{array}{c}\text { Activation } \\
\text { energies* }\end{array}$ \\
\hline & number & ${ }^{\circ} \mathrm{C}$ & kjoule/mole \\
\hline a) Leached & 4 & $910(11)$ & $369(21)$ \\
\hline b) Equilibrium & 8 & 902 (6) & $347(24)$ \\
\hline $\begin{array}{l}\text { c) Under impact of ground- } \\
\text { water }\end{array}$ & 12 & $904 \quad(9)$ & $325(23)$ \\
\hline $\begin{array}{l}\text { d) Salt or exchangeable } \mathrm{Na}^{+} \\
\text {accumulation }\end{array}$ & 27 & 899 (7.5) & $301(35)$ \\
\hline e) Lithomorphic soils ${ }^{\mathrm{x}}$ & 8 & $911(4)$ & $369(21)$ \\
\hline
\end{tabular}

Stable isotope composition

To gain more information about the formation processes of the carbonate nodules and tubules, the stable isotope ratios of these pedofeatures were determined (Table 7).

The $\delta^{13} \mathrm{C}$ and $\delta^{18} \mathrm{O}$ values of carbonates separated from chernozems or saltaffected soils (Table 7) were in, or close to, the range of recent (modern) soil carbonates (Cerling 1984). The latter range includes carbonate pedofeatures from Canadian (Wang and Anderson 1998) and Russian (Mikhailova and Post 2006) chernozems, from Natrargids in California (Amundson and Lund 1987), and from three profiles of chernozem from Hatvan-József major, Hungary (Bajnóczi 2007). Thus they may represent pedogenic carbonate accumulations.

Stable isotope compositions of tubules in salt-affected soils (Table 7) were similar to those of rhizolites in loess of SW Germany (Gocke et al. 2011) and in the margin of the Carpathians, SE Poland (Lacka et al. 2008). $\delta^{13} \mathrm{C}$ values of carbonate nodules in the subsoils of salt-affected soils (Table 7) were somewhat lower than

Table 7

Stable isotope composition of carbonates in calcareous pedofeatures

\begin{tabular}{|c|c|c|c|c|c|c|}
\hline Soil type & Location & Horizon & Ped of eatures & $\begin{array}{c}\delta^{13} \mathrm{C} \\
\text { V-PDB } \%\end{array}$ & $\begin{array}{c}\delta^{18} \mathrm{O} \\
\text { V-PDB } \% 0\end{array}$ & $\begin{array}{c}\delta^{18} \mathrm{O} \\
\text { v-SMOW, \%o }\end{array}$ \\
\hline \multirow[t]{3}{*}{ Pseudomyceliar chernozem } & \multirow[t]{3}{*}{ Baracska } & B & $\begin{array}{c}\text { needle-fiber } \\
\text { calcites }\end{array}$ & -8.7 & -7.3 & 23.4 \\
\hline & & $\mathrm{BC}$ & nodule & -8.2 & -6.4 & 24.3 \\
\hline & & $\mathrm{C}$ & nodule & -9.0 & -6.8 & 23.9 \\
\hline Chernozem brown forest soil & Bonyhád & $\mathrm{C}$ & nodule & -9.8 & -7.0 & 23.7 \\
\hline \multirow[t]{4}{*}{ Meadow solonetz } & \multirow[t]{4}{*}{ Hortobágy } & $\mathrm{BC}$ & nodule & -10.6 & -7.1 & 23.6 \\
\hline & & $\mathrm{BC}$ & tubule & -10.7 & -6.8 & 23.9 \\
\hline & & $\mathrm{C}$ & nodule & -10.5 & -6.6 & 24.1 \\
\hline & & $\mathrm{C}$ & tubule & -10.5 & -6.7 & 24.0 \\
\hline \multirow[t]{4}{*}{ Solonetzic meadow soil } & \multirow{4}{*}{ Szarvas } & $\mathrm{BC}$ & nodule & -11.0 & -6.3 & 24.4 \\
\hline & & $\mathrm{BC}$ & tubule & -10.8 & -6.4 & 24.3 \\
\hline & & $\mathrm{C}_{2}$ & nodule & -10.9 & -6.1 & 24.6 \\
\hline & & $\mathrm{C}_{2}$ & tubule & -10.7 & -6.1 & 24.6 \\
\hline
\end{tabular}


those of chernozem soils, whereas the values for $\delta^{18} \mathrm{O}$ were slightly higher. According to the compilation of Cui et al. (2011), an increase in $\delta^{13} \mathrm{C}$ - and $\delta^{18} \mathrm{O}$ values can be expected in salt-affected soils.

The data determined for carbonate nodules and tubules of the same horizons were similar. The values of nodules or tubules of various horizons in the same profile also resembled each other. This indicates that there were no important changes in the formation processes of carbonate minerals either in the $\mathrm{C}$ and $\mathrm{BC}$ horizons of the same profile, or in those of the nodules and tubules in the same horizon.

\section{Earthworm biospheroids}

During the study of the micromorphology of Hungarian soils (Szendrei 2001), earthworm biospheroids were observed in various types of soils (the $A_{p l}, A, B_{2}$ and the $C$ horizons of chernozem brown forest soils, the $C$ horizon of meadow chernozem soils, the $\mathrm{B}_{2}$ horizon of solonchak meadow soils, and the $\mathrm{H}_{2}$ and $\mathrm{H}_{3}$ horizons of soils on slope sediments). These horizons had only one common feature: the $\mathrm{CaCO}_{3}$ content was high (average: $26.1 \%$ with extremes of $13.8-52.0 \%)$.

Earlier studies primarily dealt with the morphology of the biospheroids using optical and scanning electron microscopes in order to discuss their formation processes and related factors (Becze-Deák et al. 1997; Jongmans et al. 2001; Canti and Piearce 2003; Canti 2009). The most important details focused on the fact that these biospheroids were produced by earthworms in very calcareous soils.

As pointed out earlier in connection with the cation composition of biospheroids, calcium was dominant. In the transformation of earthworm biospheroids from amorphous to more stable polymorphs of calcium carbonates, calcite is the final step (Briones et al. 2008; Gago-Duport et al. 2008).

The studied biospheroids from the $B_{2}$ horizon of a chernozem-brown forest soil consisted of calcite with traces of aragonite, suggesting that the transformation of the biospheroid material was in the final stage.

\section{Needle-fiber calcites}

The micromorphological studies of Hungarian soils (Szendrei 2001) proved that needle-fiber calcitic coatings and infillings can be found not only in zonal soils like pseudomyceliar chernozem, but also in other soil types (e.g. chernozem brown forest soil, humus carbonate and the soil of slope sediments). Needle crystals ranging from randomly-oriented to bundles were observed by SEM.

With regard to earlier data, these features were recognized by optical and scanning electron microscopy and their formation was discussed. Their biogenic origin was also taken into account (Philips and Self 1987; Jones and Kahle 1993; Verrecchia and Verrecchia 1994; Becze-Deák et al. 1997; Cailleau et al. 2009). In 
Hungary, needle-fiber calcite was found using SEM images on paleosoils from Basaharc (Pécsi 1993), and from Budapest (Bajnóczi and Kovács-Kis 2006).

The microanalysis carried out on our sample (pseudomyceliar chernozem, C horizon) did not detect magnesium, and only calcium was found. The results of the present determination were in accordance with the data of the earlier study: Bajnóczi and Kovács-Kis (2006) reported 0-2\% Mg content.

The stable isotope composition (Table 7) was in the range of figures for needlefiber calcite published earlier (Cailleau et al. 2009; Milliere et al. 2011), and these values were similar to those for Quaternary paleosoils in Hungary (Bajnóczi and Kovács-Kis 2006).

\section{Conclusions}

Although there is a wide micromorphological variety of carbonate pedofeatures of soils in Hungary, they are composed of only a few alkali earth carbonate mineral species: aragonite, calcite (+magnesian calcite) and dolomite (+ protodolomite).

It was confirmed that carbonate nodules (and partly tubules) were mainly formed by cementation of the groundmass that occurs with the component of calcium and calcium-magnesium carbonates.

There was no distinct difference in the average $\mathrm{CaCO}_{3}$ contents of nodules and tubules. The data for $\mathrm{C}^{13}$ and $\mathrm{O}^{18}$ stable isotopes of various carbonate pedofeatures (such as nodules and tubules) from the same horizons, and for the same pedofeatures from different horizons in the subsoil of chernozem and saltaffected soils, were in the same range. These data may suggest that, with regard to the aspects mentioned, these features were formed in a similar manner.

Differences among carbonate mineral associations and among the thermoanalytical data were found in substance-regime types.

Changes were recognized between the substance-regimes of soils with moderate sodium accumulation and other types of substance-regimes, in the $\mathrm{MgCO}_{3}$ content of carbonate minerals in nodules and tubules (i.e. magnesian calcite and protodolomite).

As a consequence of the above, the carbonate pedofeatures reflect several accumulation periods, e.g. with various magnesium ion concentrations in the solutions of different soils, particularly in salt-affected soils.

Biogenic calcareous components (e.g. earthworm biospheroids, needle-fiber crystals) were found mainly in soil types with equilibrium substance-regimes.

It can be concluded that differences were found in substance-regime types of soils rather than in soil types.

This mineralogical study of carbonate pedofeatures in the calcareous soils of Hungary also contributed to the knowledge of carbonate accumulation processes in soils of the European prairie ecodivisions. 


\section{Acknowledgements}

The authors wish to thank Sándor Görhely, Lajos Király, Tamás Kovács, Mihály Madarász, Géza Molnár, Gabriella Szabóné Kele, Mihály Timár, Kálmán Tompos and Tibor Tóth for their help in selecting, describing and sampling the soil profiles.

The authors are very grateful to Attila Demény for providing the data for the stable isotope compositions of selected samples.

The present work was supported by the National Scientific Research Fund (OTKA) under grant No. T023467.

\section{References}

Amundson, R.G., L.J. Lund 1987: The stable isotope chemistry of a native and irrigated Typic Natrargrid in San Joaquin valley of California. - Soil Science Society America, Proceedings, 51, pp. 761-767.

Arnold, M., P. Somogyvári, J. Paulik, F. Paulik 1987: The Derivatograph-C. A microcomputercontrolled simultaneous TG, DTG, DTA, TG and EGA apparatus. Part II. A simple method of estimating kinetic parameters. - Journal of Thermal Analysis, 32, pp. 679-683.

Bajnóczi, B. 2007: Mineralogical and geochemical studies on carbonates in special regard to carbonate facies of paleosols and metamorphic rocks. - Final reports. Posztdoktori OTKA pályázat (D 048631), 8 p. (In Hungarian.)

Bajnóczi, B., V. Kovács-Kis 2006: Origin of pedogenic needle-fiber calcite revealed by micromorphology and stable isotope composition - a case study of a Quaternary paleosol from Hungary. - Chemie der Erde, 66, pp. 203-212.

Bailey, R. 1995: Ecoregions: the Ecosystem Geography of the Oceans and Continents. - Springer. New York, $176 \mathrm{p}$.

Bal, L. 1977: The formation of carbonate nodules and intercallary crystals in the soil by the earthworm Lumbricus rubellus. - Pedobiologia, 17, pp. 102-106.

Becze-Deák, J., R. Langhor, E.P. Verrecchia 1997: Small scale secondary $\mathrm{CaCO}_{3}$ accumulations in selected sections of the European loess belt. Morphological forms and potential for paleoenvironmental reconstruction. - Geoderma, 76, pp. 221-252.

Briones, M.J., E. López, J. Méndez, J.B. Rodriguez, L. Gao-Duport 2008: Biological control over the formation and storage of amorphous calcium carbonate by earthworm. - Mineralogical Magazine, 72/1, pp. 227-231.

Bullock, P., N. Fedoroff, A. Jongerius, G. Stoops, T. Tursina, with a contribution from U. Babel 1985 Handbook for soil thin section description. - Waine Research Publications. Wolverhampton. p. 152.

Cailleau, G., E.P. Verrecchia, O. Braissant, L. Emmanuel 2009: The biogenic origin of needle-fibre calcite. - Sedimentology, 56, pp. 1858-1875.

Canti, M.G. 2009: Experiments on the origin of ${ }^{13} \mathrm{C}$ in the calcium carbonate granules produced by earthworm Lumbricus terrestris. - Soil Biology and Biochemistry, 41, pp. 2588-2592.

Canti, M.G., T.G. Piearce 2003: Morphology and dynamics of calcium carbonate granules produced by different earthworm species. - Pedobiologia, 47, pp. 511-521.

Cerling, T.E. 1984: The stable isotopic composition of modern soil carbonate and its relationship to climate. - Earth and Planetary Science Letters, 71, pp. 229-240.

Cui, YongQin, Ma, JianYing, Sun, Wei 2011: Application of stable isotope techniques to the study of soil salinization. - Journal of Arid Land, 3/4, pp. 285-291.

Darab, K., M. Reményi 1978: Properties of magnesium affected soils and their micromineralogical compositions. - Agrokémia és Talajtan, 27, pp. 357-375 (In Hungarian.) 
Demény, A., I. Fórizs 1991: On some preparation methods in stable isotope mass spectrometry and their geochemical applications. - Rapid Communications in Mass Spectrometry, 11, pp. 524-526.

Doner, H.E., W.C. Lynn 1989: Carbonate, halide, sulfate and sulfide minerals. In: Minerals in Soil Environments. - Soil Science Society of America, Inc. Madison Book Series, No 1, Madison, pp. 279-330.

Doner, H.E., P. R. Grossl 2002: Carbonates and evaporites. - In: Soil Mineralogy with Environmental Applications. - Soil Science Society of America, Inc. Madison, Book Series, No 7, pp. 199-227.

Durand, N., H. Curtis Monger, M.G. Canti 2010: Calcium Carbonate Features. - In: Stoops, G., V. Marcelino, F. Mees (Eds): Interpretation of Micromorphological Features of Soils and Regoliths. Elsevier, Amsterdam, pp. 149-193.

FAO/ISRIC/ISSS 1998: World Reference Base for Soil Resources, World Soil Resources Report, No. 84, FAO - Rome.

Földvári, M. 1999: The use of corrected thermal decomposition temperature in the geological interpretation. - Journal of Thermal Analysis and Calorimetry, 56, pp. 909-916.

Fujimori, H., T. Oonori, S. Kochi, T.A. Prolla, S. Someya 2006: Synthesis of protodolomite from coral reef sand. - Food Chemistry, 99, pp. 15-18.

Gago-Duport, L., M.J.I. Briones, J.B. Rodrígez, B. Covelo 2008: Amorphous calcium carbonate biomineralization in the earthworm's calciferous gland: Pathways to formation of crystalline phases. - Journal of Structural Biology, 162, pp. 422-435.

Gerasimova, M.I., S.V. Gubin, S.A. Shoba 1996: Soils of Russia and adjacent countries: geography and micromorphology. Moscow - Wageningen. p. 204.

Ghebre-Egziabhier, K., R.J. St. Arnaud 1983: Carbonate mineralogy of lake sediments and surrounding soils. 2. The Qu'Appelle lakes. - Canadian Journal of Soil Science, 63, pp. 259-269.

Gocke, M., K. Pustovoytov, P. Kühn, G.L.B. Wiesenberg, M. Löscher, Y. Kuzyakov 2011: Carbonate rhizoliths in loess and their implications for paleoenvironmental reconstruction revealed by isotopic composition: $\delta^{13} \mathrm{C},{ }^{14} \mathrm{C}$. - Chemical Geology, 283, pp. 251-260.

Graf, D.L., J.R. Goldschmidt 1955: Some hydrothermal synthesis of dolomite and protodolomite. Journal of Geology, 64, pp. 173-187.

Jones, B., C. Kahle 1993: Morphology, relationship, and origin of fiber and dendrite calcite crystals. Journal of Sedimentary Petrology, 63/6, pp. 1018-1031.

Jongmans, A.G., M.M. Pulleman, J.C.Y. Marinissen 2001: Soil (micro) structure and earthworm activity in a marine loam under different management. - International Working Meeting on Micropedology. Programme and Abstracts. Universiteit Gent, 48 p.

Kovács-Pálffy, P., M. Földvári, E. Rálisch-Felgenhauer, K. Baráth-Sinyey 2000: Mineralogical characterisation of the fissure fillings in the Üveghuta granite. - Annual Report of the Geological Institute of Hungary, 1999, pp. 353-378.

Łacka, B., M. Łanczont, M. Komar, T. Madeyska 2008: Stable isotope composition of carbonates in loess at the Carpathian margin (SE Poland). - Studia Quaternaria, 25, pp. 3-21.

Lal, R., J.M. Kimble, H. Eswaran, B.A. Stewart (Eds): 2000: Global climate change and pedogenic carbonates. - Lewis Publishers, Boca Raton, London, 303 p.

Lavado, R.S. 1983: Occurrence of magnesium-bearing calcites in pampean soils, Argentina. Geoderma, 29, pp. 59-66.

McCrea, J.M. 1950: On the isotopic chemistry of carbonates and a paleotemperature scale. - Journal of Chemical Physics, 18, pp. 849-857.

Micheli, E., M. Fuchs, P. Hegymegi, P. Stefanovits 2006: Classification of the major soils of Hungary and their correlation with the World Reference Base for Soil Resources. - Agrokémia és Talajtan, 55, pp. 19-28. (In Hungarian.)

Mikhailova, E.A., C.J. Post 2006: Stable carbon and oxygen isotopes of soil carbonates at depth in the Russian chernozem under different land use. - Soil Science, 171/4, pp. 334-340.

Milliere, L., O. Hasinger, S. Bindschedler, G. Cailleau, J. Spangenberg, E.P. Verrecchia 2011: Stable carbon and oxygen isotope signatures of pedogenic needle fibre calcite. - Geoderma, 161, pp. 74-87. 
Molnár, B., R. Botz 1996: Geochemistry and stable isotope ratio of modern carbonates in natron lakes of the Danube-Tisza Interfluve, Hungary. - Acta Geologica Hungarica, 39/2, pp. 153-174.

Molnár, B., M. Dinka 1997: Formation of carbonate deposits in Hungarian part of Fertó lake. Hidrológiai Közlöny, 77/3, pp. 115-122.

Mucci, A., W. Morse 1983: The incorporation of $\mathrm{Mg}^{2+}$ and $\mathrm{Sr}^{2+}$ into calcite overgrowths: influences of growth rate and solution composition. - Geochimica and Cosmochimica Acta, 47, pp. 217-233.

Müller, G., F. Wagner 1980: Formation of carbonate deposits of Balaton lake, reflections of climatic and human impacts. - Hidrológiai Közlöny, 60/11, pp. 509-518. (In Hungarian.)

Ohde, S., Y. Kitano 1978: Synthesis of protodolomite from aqueous solution at normal temperature and pressure. - Geochemical Journal, 12, pp. 115-119.

Oomori, T., K. Kaneshima, T. Taira, Y. Kitano 1983: Synthetic studies of protodolomite from brine waters. - Geochemical Journal, 17, pp. 147-152.

Pécsi, M. 1993: Quaternary and loess research. - Akadémiai Kiadó. Budapest. 375 p. (In Hungarian.)

Philips, S.E., P.G. Self 1987: Morphology, crystallography and origin of needle-fibre calcite in Quaternary pedogenic calcretes of South Australia. - Australian Journal of Soil Research, 25, pp. 429-444.

Sisák, I., F. Máté 2008: The necessity of further development of Hungarian soil classification experience of soil monolit series "Soils of Balaton Landscapes". Talajvédelem. Különszám. Talajvédelmi Alapítvány - Bessenyei György Könyvkiadó, Nyíregyháza, pp. 653-662. (In Hungarian.)

St. Arnaud, R.J. 1979: Nature and distribution of secondary soil carbonates within landscapes in relation to soluble $\mathrm{Mg}^{++} / \mathrm{Ca}^{++}$ratios. - Canadian Journal of Soil Science, 59, pp. 87-98.

St. Arnaud, R.J., A.J. Herbillon 1973: Occurrence and genesis of secondary magnesium-bearing calcites in soils. - Geoderma, 9, pp. 279-298.

Stoops, G. 2003: Guidelines for Analysis and Description of Soil and Regolith Thin Sections. - Soils Science Society of America, Madison. $184 \mathrm{p}$.

Suarez, D. L. 2005: Chemistry of Salt-Affected Soils. - In: Chemical Processes in Soils. Soil Science Society of America, Inc., Madison, Book Series, No. 8., pp. 689-705.

Szabolcs, I. (Ed.) 1966: Handbook for genetic, large scale soil mapping. - Országos Mezőgazdasági Minőségvizsgáló Intézet, Budapest, 351 p. (In Hungarian.)

Szemethy, A. 1975: X-ray research of the carbonate minerals of Neogene borehole samples. - A Magyar Állami Földtani Intézet Évi Jelentés az 1975. évről, pp. 303-314. (In Hungarian.)

Szendrei, G. 2000: Soil micromorphology. - ELTE Eötvös Kiadó, Budapest. 220 p. (In Hungarian.)

Szendrei, G. 2001: Micromorphology of Hungarian soils. - Aula, Budapest, 163 p. (In Hungarian.)

Szöőr, Gy., I, Barta, É. Balázs, P. Sümegi 1992: Geochemical facies analysis of Quaternary pelitic deposits of Northeast Lowland. - In: Szöőr, Gy.: Facies analytical, paleobiogeochemical and paleoecological researches. Magyar Tudományos Akadémia Debreceni Akadémiai Bizottság, Debrecen, pp. 45-64. (In Hungarian.)

Várallyay, Gy. 1985: Moisture and substance regimes of Hungarian soils. - Agrokémia és Talajtan. 34/3-4. pp. 267-299. (In Hungarian.)

Verrecchia, E.P., K.E. Verrecchia 1994: Needle-fiber calcite: a critical review and proposed classification. - Journal of Sedimentary Research, 64/3, pp. 650-664

Wang, D., D.W. Anderson 1998: Stable carbon isotopes of carbonate pendants from chernozemic soils of Saskatchewan, Canada. - Geoderma, 84, pp. 309-322.

Warren, J. 2000: Dolomite: Occurrence, evolution and economically important associations. Earth-Science Review, 52, pp. 1-81. 